
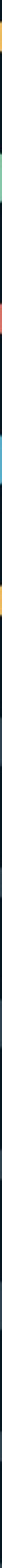

VIOLENCE, SECTARIANISM AND REVOLUTION IN THE MIDDLE EAST

SIMON MABON 


\section{Houses built on sand}

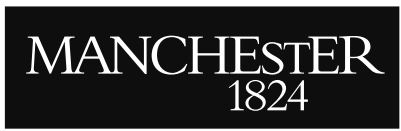

Manchester University Press 


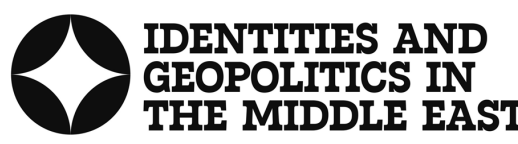

Series editors: Simon Mabon, Edward Wastnidge and May Darwich

After the Arab Uprisings and the ensuing fragmentation of regime-society relations across the Middle East, identities and geopolitics have become increasingly contested, with serious implications for the ordering of political life at domestic, regional and international levels, best seen in conflicts in Syria and Yemen. The Middle East is the most militarised region in the world, where geopolitical factors remain predominant in shaping political dynamics. Another common feature of the regional landscape is the continued degeneration of communal relations as societal actors retreat into substate identities, while difference becomes increasingly violent, spilling out beyond state borders. The power of religion - and trans-state nature of religious views and linkages - thus provides the means for regional actors (such as Saudi Arabia and Iran) to exert influence over a number of groups across the region and beyond. This series provides space for the engagement with these ideas and the broader political,

legal and theological factors to create space for an intellectual reimagining of socio-political life in the Middle East.

Originating from the SEPAD project (www.sepad.org.uk), this series facilitates the reimagining of political ideas, identities and organisation across the Middle East, moving beyond the exclusionary and binary forms of identity to reveal the contingent factors that shape and order life across the region. 


\section{Houses built on sand \\ Violence, sectarianism and revolution in the Middle East}

Simon Mabon

Manchester University Press 
Copyright $\odot$ Simon Mabon 2020

The right of Simon Mabon to be identified as the author of this work has been asserted by him in accordance with the Copyright, Designs and Patents Act 1988.

This electronic version has been made freely available under a Creative Commons (CC-BY-NC-ND) licence, which permits non-commercial use, distribution and reproduction provided the author(s) and Manchester University Press are fully cited and no modifications or adaptations are made.

Details of the licence can be viewed at https://creativecommons.org/licenses/by-nc-nd/4.0/

\author{
Published by Manchester University Press \\ Altrincham Street, Manchester M1 7JA \\ www.manchesteruniversitypress.co.uk \\ British Library Cataloguing-in-Publication Data \\ A catalogue record for this book is available from the British Library
}

ISBN 9781526126467 hardback

ISBN 9781526126474 open access

First published 2020

The publisher has no responsibility for the persistence or accuracy of URLs for any external or third-party internet websites referred to in this book, and does not guarantee that any content on such websites is, or will remain, accurate or appropriate.

Typeset by Newgen Publishing UK 